\title{
Differential Effects of Myocilin and Optineurin, Two Glaucoma Genes, on Neurite Outgrowth
}

Takahisa Koga, Xiang Shen, Jeong-Seok Park, Ye Qiu, Bum-Chan Park, Rajalekshmy Shyam, and Beatrice Y.J.T. Yue

From the Department of Ophthalmology and Visual Sciences, University of Illinois at Chicago, College of Medicine,

Chicago, Illinois

Myocilin and optineurin are two genes linked to glaucoma, a major blinding disease characterized by progressive loss of retinal ganglion cells (RGCs) and their axons. To investigate the effects of force-expressed wild-type and mutant myocilin and optineurin on neurite outgrowth in neuronal cells, we transiently transfected cells with pEGFP-N1 (mock control) as well as myocilin and optineurin plasmids including pMYOC $_{\text {wT }}$-EGFP, pMYOC $_{\text {P370 }}$-EGFP, PMYOC $_{1-367}$-EGFP, POPTN $_{W T}-$ EGFP, and POPTN $_{\text {E5OK }}$-EGFP. PC12 cells transfected with PEGFP-N1 produced, as anticipated, long and extensive neuritis on nerve growth factor induction. The neurite length in those cells transfected with myocilin constructs was shortened and the number of neurites was also reduced. A similar inhibitory effect on neurite outgrowth was also elicited by myocilin transfection in RGC5 cells. In contrast, neither transfection of the optineurin constructs POPTN $\mathrm{WT}_{\mathrm{WT}}$-EGFP and POPTN ${ }_{\mathrm{E} 50 \mathrm{~K}}$-EGFP nor the myocilin and optineurin small-interfering RNA treatments induced significant alterations in neurite outgrowth. Transfection with the wild-type optineurin construct, but not with that of the wild-type myocilin, increased the apoptotic activity in cells. These results demonstrated that the two glaucoma genes, myocilin and optineurin, exhibited differential effects on neurite outgrowth. They may contribute to the development of neurodegenerative glaucoma via distinct mechanisms. (Am J Pathol 2010, 176:343-352; DOI: 10.2353/ajpath.2010.090194)

Glaucoma, one of the leading causes of irreversible blindness worldwide, is characterized by progressive loss of retinal ganglion cells (RGCs) and their axons. Primary open-angle glaucoma (POAG), the most com- mon form of glaucoma, is frequently associated with increased intraocular pressure (IOP). The IOP is controlled by a balance between the production and outflow of the aqueous humor contained in the anterior chamber. The trabecular meshwork (TM), a specialized eye tissue neighboring the cornea, is the major site for regulation of the aqueous humor outflow. ${ }^{1}$

Recent studies have revealed that POAG is genetically heterogeneous, caused by several susceptibility genes and environmental factors. ${ }^{2}$ To date, a total of 14 chromosomal loci have been mapped and designated as GLC1A to GLC1N. 3,4 Three candidate genes have been identified that include myocilin as the GLC1A, ${ }^{5,6}$ optineurin as the GLC1E, ${ }^{7,8}$ and WDR36 as the GLC1G gene.

Myocilin is the first identified gene for both juvenile- and adult-onset POAG. ${ }^{6}$ More than 70 myocilin mutations have been found in a number of families. ${ }^{10}$ Patients with glaucoma with myocilin mutation tend to have high IOP. ${ }^{11,12}$ Among the myocilin mutations, the Gln368Stop (Q368X) mutation is the most frequent ${ }^{10}$ and the Pro370Leu (P37OL) mutation is responsible for one of the most severe glaucoma phenotypes. ${ }^{13-15}$

The human myocilin gene encodes a protein of 504 amino acids, containing a nonmuscle myosin-like domain near the amino (N)-terminus and an olfactomedin-like domain at the carboxyl (C)-terminus. ${ }^{16}$ Myocilin interacts with itself and a number of other proteins, mainly through the leucine zipper motif and a coiled-coil region in the myosin-like domain. ${ }^{17-19}$ The wild-type myocilin is a secreted protein. Mutants with mutations in the olfatomedinlike domain, however, are not secreted. They are retained

Supported by grants EY005628, EY018828, and EY003890 (to B.Y.J.T.Y.) and core grant EY001792 from the National Eye Institute, Bethesda, Maryland; and the Komarek-Hyde-McQueen Foundation Glaucoma Research Fund created in honor of Dr. Mark W. Lunde. Acknowledgement is also made to the donors of ADR, a program of the American Health Assistance Foundation, Clarksburg, Maryland, for support of this research.

Accepted for publication September 8, 2009

Address reprint requests to Beatrice Y.J.T. Yue, Ph.D., Department of Ophthalmology and Visual Sciences, University of Illinois at Chicago, College of Medicine, 1855 W. Taylor St, Chicago, IL 60612. E-mail: beatyue@uic.edu. 
in the cells, aggregating to cause endoplasmic reticulum stress. ${ }^{20-22}$

Optineurin, identified in $2002,^{8}$ is a gene that links principally to normal tension glaucoma, a subtype of POAG. ${ }^{23}$ Optineurin mutations were noted to vary with ethnic background. 24,25 The Glu50Lys (E50K) mutation, found in Caucasian and Hispanic populations, ${ }^{25}$ seems to be associated with a more progressive and severe disease in patients with normal tension glaucoma. ${ }^{26}$

The human optineurin gene codes for a 577-amino acid protein that contains multiple coiled-coil domains and a C-terminal zinc finger. ${ }^{27,28}$ The optineurin protein from different species has high amino acid homology. ${ }^{28}$ The amino acid 50 glutamic acid residue is conserved in mice, rats, chickens, and cows. ${ }^{23}$ Optineurin is expressed in many tissues including the brain and the retina. $^{27,28}$

Despite intense interest, the roles of myocilin and optineurin in cellular functions still remain largely undefined. Because glaucoma is a group of diseases known as progressive optic neuropathies, we undertook the current study to investigate the effects of myocilin and optineurin on neurite outgrowth. We demonstrated that overexpression of wild-type myocilin or P370L and Q368X mutants caused an inhibition of neurite outgrowth, whereas forced expressed wild-type or E50K optineurin did not result in any changes in neuronal rat pheochromocytoma $\mathrm{PC} 12^{29}$ and $\mathrm{RGC5} 5^{30}$ cells.

\section{Materials and Methods}

\section{Cell Cultures}

Rat PC12 cells were obtained from the American Type Culture Collection (Manassas, VA). The cells were grown at $37^{\circ} \mathrm{C}$ in $5 \% \mathrm{CO}_{2}$ in RPMl 1640 medium (Sigma, St. Louis, MO) containing 5\% fetal bovine serum (FBS) and $10 \%$ calf serum. ${ }^{31}$ Rat retinal ganglion RGC5 cells were obtained from the departmental core facility, deposited by Dr. Paul Knepper, ${ }^{32}$ generously provided originally by Dr. Neeraj Agarwal (North Texas Health Science Center, Fort Worth, TX). RGC5 cells were grown in Dulbecco's modified Eagle's medium supplemented with 10\% FBS and antibiotics. ${ }^{31}$ Normal human eyes from 22- to 55year-old donors were obtained from the Illinois Eye Bank (Chicago, IL). Human TM cells were cultured as described previously ${ }^{33,34}$ on Falcon Primaria flasks in complete media containing Dulbecco's modified Eagle's medium, 10\% FBS, 5\% calf serum, and antibiotics. Dexamethasone $(10 \mathrm{nmol} / \mathrm{L})$ treatment was performed for 10 days as previously described. ${ }^{34}$

\section{Plasmids}

Wild-type human myocilin (MYOC) open reading frame was PCR-amplified against PRSET-MYOC ${ }^{35}$ and cloned into pTarget (Promega, Madison, WI) to generate pTargetMYOC $_{W T}{ }^{33}$ pMYOC $_{W T}$-EGFP was constructed by PCR amplification of MYOC $_{W T}$ from pTarget-MYOC ${ }_{W T}$ by using 5'-GGCGGATCCCGCATCTTGGAGAGCTT-
GATGTC-3' (BamHI site in italics) sense and 5'-GGCGAATTCCCACCATGGCTATGAGGTTCTTCTGTGCACG-3' (EcoRl site in italics) antisense primers. The EcoRI/BamHI-digested PCR product was cloned into pEGFP-N1 (BD Biosciences, St. Jose, CA) at the corresponding sites. The mutant myocilin construct, pMYOC $_{\mathrm{P} 370 \mathrm{~L}}-\mathrm{EGFP}$, was generated from $\mathrm{PMYOC}_{\mathrm{WT}^{-}}$ EGFP by using QuikChange II Site-Directed Mutagenesis Kit (Stratagene, La Jolla, CA), sense 5'-CCACGGACAGTTCCTGTATTCTTGGGGTGGC-3' (nucleotides for P370L change in italics) primer, and the antisense primer. Myocilin construct with Q368X mutation, pMYOC 1-367 $^{-E G F P, ~ g e n e r a t e d ~ b y ~ P C R ~ b y ~ u s i n g ~}$ 5'-GGCGAATTCCCACCATGGCTATGAGGTTCTTCTGTGCACGTTG (EcoRI site in italics) sense and 5'-GGCGGATCCCGTCCGTGGTAGCCAGCTCC-3' (BamHI site in italics) antisense primers was cloned in frame into pEGFP-N1. Sequencing was performed to determine the proper orientation and confirm the construct sequences. Optineurin (OPTN) plasmids pOPTN ${ }_{W T}-E G F P$ and POPTN $\mathrm{E}_{\mathrm{EOK}}$-EGFP were constructed as described previously. ${ }^{36}$

\section{Transient Transfection}

PC12 and RGC5 cells were plated onto Falcon Primaria plates with (for PC12) or without (for RGC5) precoating of the wells overnight at $4^{\circ} \mathrm{C}$ with $10 \mu \mathrm{g} / \mathrm{ml}$ of bovine collagen type I (BD Biosciences). The medium was replaced with RPMI 1640 medium containing 1\% FBS 1 hour before the transfection. Transient transfection was performed by using lipofectamine LTX and Plus reagent (Invitrogen, Carlsbad, CA) for 24 to 48 hours according to the manufacturer's protocol.

For small-interfering RNA (siRNA)-mediated knock down, PC12 cells were plated in complete media at 80 to $90 \%$ confluency overnight. The cells were transfected with 50 to $100 \mathrm{nmol} / \mathrm{L}$ of myocilin or optineurin siRNA duplex (Dharmacon, Lafayette, CO) along with Cy3-labeled luciferase GL2 duplex (Dharmacon) for 48 hours by using TransIT-TKO transfection reagent (Mirus Bio Corporation, Madison, WI). Myocilin siRNA was from an on-target plus smart pool of 4 siRNAs specific for rat myocilin. Target sequence of optineurin siRNA was 5'GAAGCCATGAAGCTAAATA-3' and matched to 166 to $184 \mathrm{bp}$ of rat optineurin sequence. As a control, a 19nucleotide scrambled siRNA (Dharmacon) was used.

\section{Neurite Outgrowth Measurements}

PC12 cells (10,000 cells/well) on collagen type I-coated 24-well plates were transfected with $0.5 \mu \mathrm{g}$ of plasmid DNA or 50 to $100 \mathrm{nmol} / \mathrm{L}$ of siRNA for 48 hours. The cells were washed and fed with RPMI 1640 medium containing $1 \% \mathrm{FBS}$ and $100 \mathrm{ng} / \mathrm{ml}$ of nerve growth factor (NGF; Peprotech, Rocky Hill, NJ) to induce differentiation. In some experiments, $10 \mu \mathrm{mol} / \mathrm{L}$ of $Y 27632$ (Calbiochem, La Jolla, CA), $10 \mu \mathrm{mol} / \mathrm{L}$ of forskolin (Calbiochem), $0.8 \mu \mathrm{mol} / \mathrm{L}$ of 15-deoxy-prostagrandin J2 (15-deoxy-PGJ2, Sigma), 0.5 $\mu \mathrm{mol} / \mathrm{L}$ of $4-\beta$-phorbol 12-myristate 13 -acetate (PMA, Cal- 
biochem) or $20 \mathrm{nmol} / \mathrm{L}$ of jasplakinolide (Calbiochem) was added into the media. After 5 days, cells were photographed by using phase contrast and fluorescence Axioscope (Carl Zeiss Microlmaging, Thornwood, NY). Extensions longer than $15 \mu \mathrm{m}$ were considered as neurites. The length of neurites was measured and the number of neurites was counted in at least 50 cells with the aid of MetaMorph software (Molecular Devices, Downingtown, PA). Data were statistically analyzed by Student's $t$ tests. The intracellular cyclic AMP (cAMP) level in PC12 cells after transfection with pTarget-MYOC $\mathrm{CT}_{\mathrm{WT}}$ was measured by using the Parameter cAMP assay kit (R and D Systems, Minneapolis, MN) following manufacturer's instructions.
RGC5 cells (5000 cells/well) were plated onto 24-well Falcon Primaria plates. After transiently transfection with $0.5 \mu \mathrm{g}$ of plasmid DNA for 48 (for myocilin constructs) or 24 (for optineurin constructs) hours, the cells were differentiated with $316 \mathrm{nmol} / \mathrm{L}$ staurosporine for another 4 hours $^{37}$ and photographed by using Axioscope (Carl Zeiss Microlmaging). Neurite outgrowth was quantified.

\section{Transgene Expression}

PC12 cells $(50,000$ cells/well) plated onto 6-well plates precoated with collagen type I were transfected with $2.5 \mu \mathrm{g}$ of
A
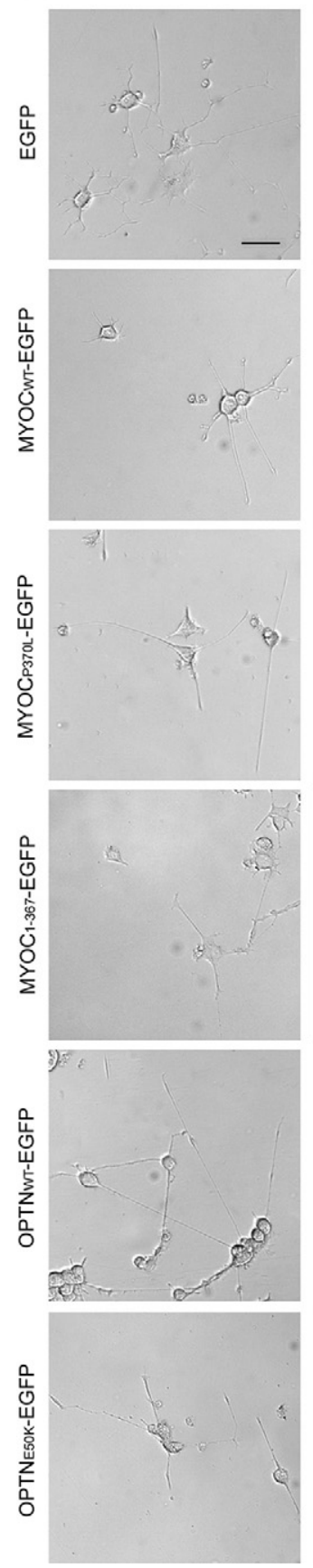
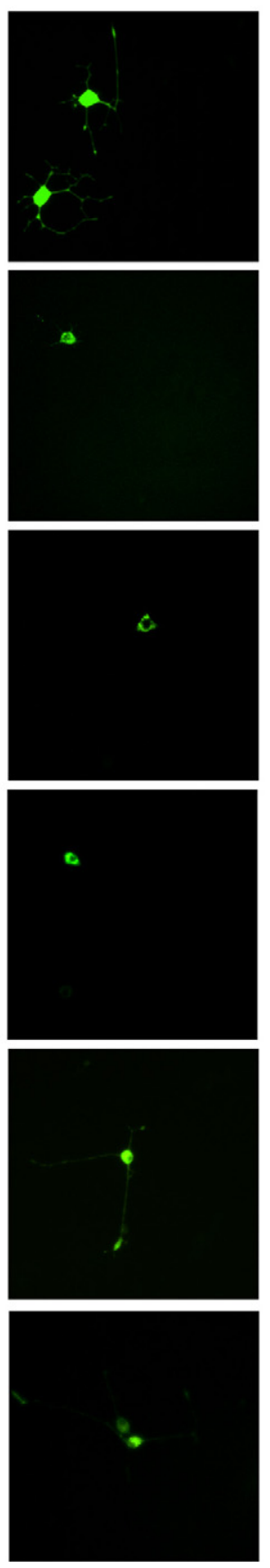

B
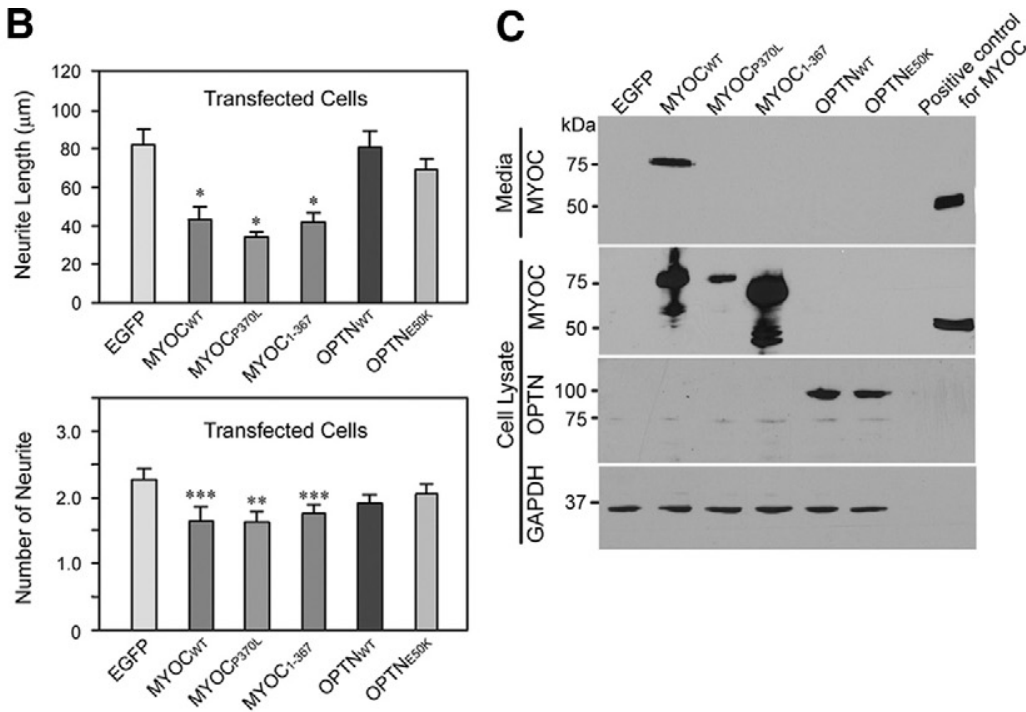
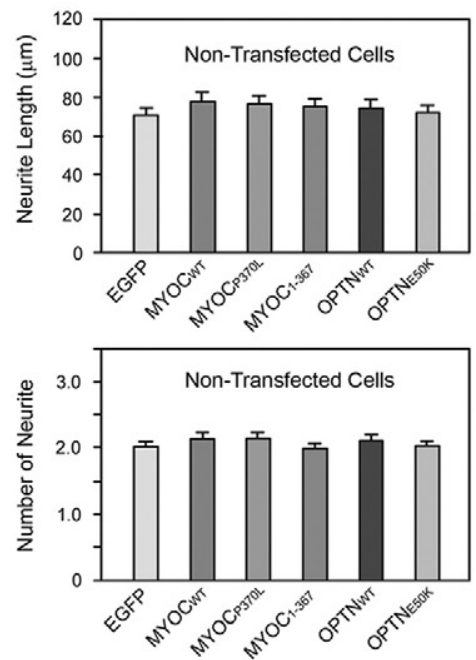

Figure 1. Effect of overexpression of wild-type and mutant myocilin and optineurin on neurite outgrowth in PC12 cells. A: Phase contrast and fluorescence micrographs of cells transiently transfected with pEGFP-N1 (mock control), pMYOC ${ }_{\mathrm{WT}}$-EGFP, pMYOC ${ }_{\mathrm{P} 370 \mathrm{~L}}$-EGFP, pMYOC $_{1-367}$-EGFP,

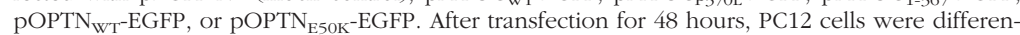
tiated with NGF treatment for 5 days. Images on the right show the transgene expression in green in transfected cells. Scale bar $=50 \mu \mathrm{m}$. B: The length and the number of neurites were measured in at least 50 transfected green cells and in at least 150 nontransfected cells. Results are expressed as mean \pm SEM. Data were statistically analyzed by using Student's $t$ tests. ${ }^{*} P<0.0005$; ${ }^{* * *} P<$ 0.004 ; and ${ }^{* * * *} P<0.02$ versus pEGFP-N1. C: Protein extract $(80 \mu \mathrm{g})$ or $50 \mu \mathrm{l}$ of medium from transfected cultures was subjected to immunoblotting with anti-myocilin (MYOC), anti-optineurin (OPTN), or anti-GAPDH (GAPDH). A major band of myocilin-GFP or optineurin-GFP was observed. Media collected from dexamethasone-treated human TM cells, used as a positive control, contained a myocilin $(\sim 55 \mathrm{kDa})$ protein band. 
plasmid DNA for 48 hours. Transfected cells were treated with $100 \mathrm{ng} / \mathrm{ml}$ of NGF for 96 hours. The media were collected and cells were lysed in CellLytic-M cell lysis reagent (Sigma) containing protease inhibitor cocktail (Roche, Indianapolis, IN). The protein content in the lysate was determined by using the bicinchoninic acid protein assay kit (Pierce, Rockford, IL). A total of $80 \mu \mathrm{g}$ of protein from the lysate or $50 \mu \mathrm{l}$ of media was subjected to $10 \%$ SDS-polyacrylamide gel electrophoresis under reducing conditions, and transferred to nitrocellulose membranes (Protran BA83, Whatman, Sanford, ME). The blot was blocked for 45 minutes with $5 \%$ nonfat dry milk in Tris-buffered saline containing $0.1 \%$ Tween 20 and was subsequently incubated at $4^{\circ} \mathrm{C}$ overnight with goat polyclonal anti-myocilin antibody (N15, Santa Cruz Biotechnology, Santa Cruz, CA) at 1:250 dilution, rabbit polyclonal anti-optineurin (C-terminal) antibody (Cayman Chemical, Ann Arbor, MI) at 1:1000 dilution, or rabbit polyclonal anti-glyceraldehyde 3-phosphate dehydrogenase (GAPDH) antibody (Trevigen, Gaithersburg, MD) at 1:6500 dilution. After washing with Tris-buffered saline containing $0.1 \%$ Tween 20 , the membrane was incubated for 1 hour at room temperature with horseradish peroxidase-conjugated secondary antibody (1:10,000; Jackson ImmunoReserch Laboratories, West Grove, PA). The immunoreactive bands were visualized with SuperSignal Substrate (Pierce). For repeated probing, the blot was stripped for 30 minutes at room temperature with ImmunoPure IgG Elution buffer (Pierce).

\section{Effects of Exogenous Recombinant Myocilin on Neurite Outgrowth}

Eukaryotically expressed recombinant myocilin protein was purified as previously described ${ }^{33,38}$ from conditioned media of a transformed TM cell line, TM5, provided by Dr. Mike Fautsch at the Mayo Clinic. The TM5 cells were transduced with feline immunodeficiency virus that contains full length human myocilin fused to C-terminal His and V5 tags.

PC12 cells were incubated for 5 days with Dulbecco's modified Eagle's medium containing 1\% FBS and 100 $\mathrm{ng} / \mathrm{ml}$ NGF without or with eukaryotically expressed recombinant myocilin protein $(1.8,5$, and $20 \mathrm{nmol} / \mathrm{L})$. Bovine serum albumin $(20 \mathrm{nmol} / \mathrm{L})$ was used as a control. Photographs of the cells were taken and the length of neurites was measured. In additional experiments, Falcon Primaria 24-well plates were coated at $4^{\circ} \mathrm{C}$ overnight with collagen type I $(10 \mu \mathrm{g} / \mathrm{ml})$ alone or with collagen type I $(10 \mu \mathrm{g} / \mathrm{ml})$ mixed with recombinant myocilin $(5 \mu \mathrm{g} / \mathrm{ml})$. PC12 cells (10,000 cells/well) plated onto these coated wells were cultured overnight, treated with NGF for 5 days, and photographed. The length and number of neurites were determined as above.

\section{Internalization of Fluorescein Isothiocyanate-Labeled Recombinant Proteins into Cells}

The eukaryotically expressed recombinant myocilin, human holo-transferrin (Sigma, positive control), or recombinant $\beta$-galactosidase (negative control) ${ }^{39}$ was conjugated with fluorescein isothiocyanate (FITC) by using EZ-label FITC protein labeling kit (Pierce). Briefly, $0.5 \mathrm{mg}$ of myocilin was exchanged into $50 \mathrm{mmol} / \mathrm{L}$ of borate buffer ( $\mathrm{pH}$ 8.5) by dialysis. Transferrin ( $1 \mathrm{mg}$ ) or $\beta$-galactosidase $(1 \mathrm{mg})$ was directly dissolved in borate buffer. An appropriate amount of FITC was added to each protein and incubated at room temperature for 1 hour. The sample was dialyzed with phosphate buffered saline (PBS) to remove uncoupled FITC and to exchange borate buffer to PBS. The protein content was determined by bicinchoninic acid protein assay.

PC12 and RGC5 cells were incubated for 4 hours at $37^{\circ} \mathrm{C}$ with $25 \mu \mathrm{g} / \mathrm{ml}$ of FITC-labeled myocilin, transferrin, or $\beta$-galactosidase. The cells were washed with PBS and photographed by using Axioscope (Carl Zeiss Microlmaging).

\section{Apoptosis}

Apoptosis was evaluated by the BIOMOL CV-caspase 3 and 7 detection kit (Enzo Life Sciences, Inc, Farmingdale, NY) that utilizes the fluorophore, cresyl violet, coupled to the C-terminus of the optimal tetrapeptide recognition sequences for caspases 3 and 7, DEVD [CR(DEVD) $)_{2}$. Cleavage of the target sequences by activated enzymes yields a red fluorescent product throughout the cell, indicative of apoptotic activity. PC12 and RGC5 cells on glass chamber slides were transiently transfected for 48 hours to express wild-type, P370L, or Q368X (1-367) myocilin-green fluores-

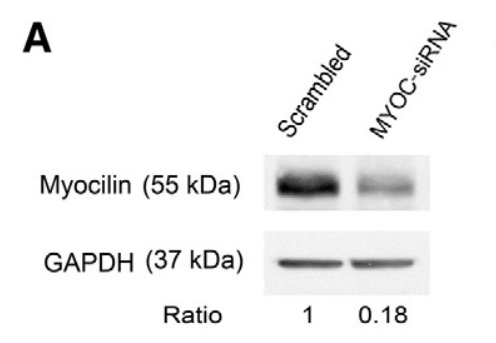

B
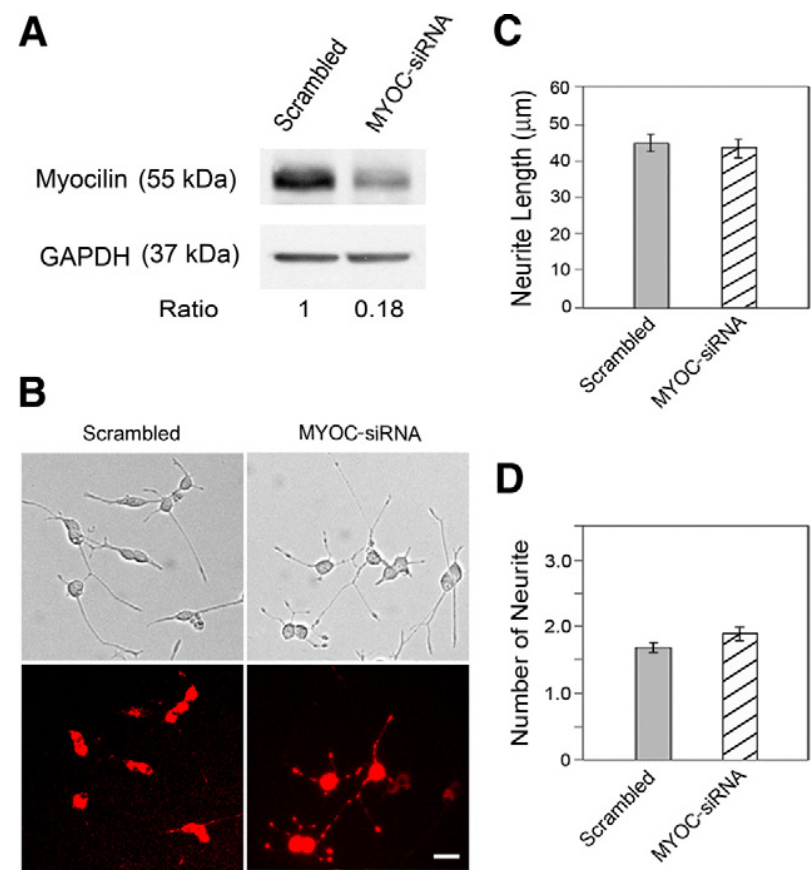

D

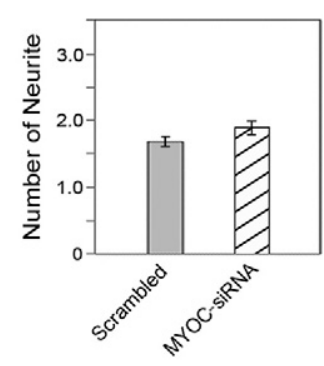

Figure 2. Effect of myocilin siRNA treatment on neurite outgrowth in PC12 cells. A: The cells were transfected with either $50 \mathrm{nmol} / \mathrm{L}$ scrambled (lane 1) or rat myocilin-specific siRNAs (lane 2) for 48 hours. The cells were lysed and immunoblotted with anti-myocilin antibody to evaluate the efficiency of myocilin knockdown. Anti-GAPDH was used to control protein loading. B: Phase contrast and fluorescence micrographs of PC12 cells transfected with either scrambled or myocilin siRNAs (MYOC-siRNA) along with Cy3labeled luciferase GL2 duplex. The cells were incubated with NGF for 5 days and the neurite outgrowth was evaluated as described in Figure 1. The siRNA transfected cells were marked by red fluorescence. The transfection efficiency is nearly $100 \%$. Scale bar $=20 \mu \mathrm{m}$. C: The average length of neurites was determined. D: The number of neurites per cell was counted. Data presented were mean \pm SEM from a representative experiment. Three experiments were performed with similar results. 
cence protein (GFP), or 24 hours to express wild-type or E50K optineurin-GFP. They were subsequently incubated with $\mathrm{CR}(\mathrm{DEVD})_{2}$ for 60 minutes. As a positive control, cells were treated with $4 \mu \mathrm{mol} / \mathrm{L}$ staurosporine overnight before the procedure. The slides were mounted in Vectashield with 4', 6-diamidino-2-phenylindole (DAPI, Vector Laboratories, Burlingame, CA), which stains nuclei of all transfected (green) and nontransfected cells.

The total number of DAPI-stained transfected cells (green) and the number of CR(DEVD) $)_{2}$-stained transfectants (displaying both green and red fluorescence) in 20 of randomly selected $10 x$ fields were counted. The percentage of caspase 3/7-positive apoptotic cells in approximately 100 transfectants was calculated. All experiments were repeated at least three times. Statistical analysis was performed by using Student's $t$ tests.

\section{Results}

\section{Overexpression of Wild-Type and Mutant Myocilin, but not Optineurin, Inhibits Neurite Outgrowth}

To examine whether glaucoma genes myocilin and optineurin are involved in neuronal differentiation, wild-type and mutant plasmids were transiently transfected into
A

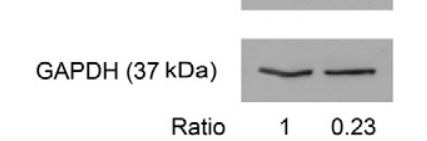

B

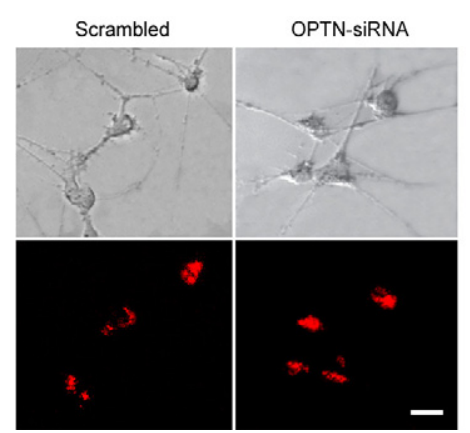

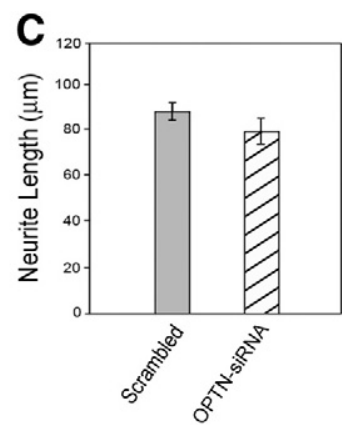

D

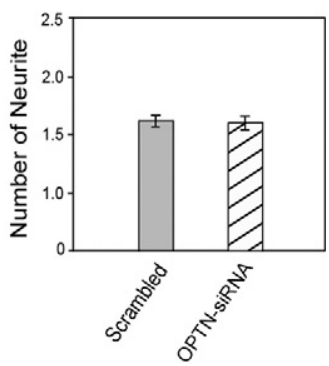

Figure 3. Effect of optineurin siRNA treatment on neurite outgrowth in PC12 cells. A: The cells were transfected with $100 \mathrm{nmol} / \mathrm{L}$ scrambled (lane 1) or optineurin-specific siRNA (lane 2) for 48 hours. The cell lysates were immunoblotted with anti-optineurin antibody and anti-GAPDH (to control for protein loading). B: The effect of optineurin depletion on neurite outgrowth PC12 cells transfected with either scrambled or optineurin siRNA (OPTNsiRNA) along with Cy3-labeled luciferase GL2 duplex were incubated with NGF for 5 days. The neurite outgrowth was quantified. The siRNA transfected cells were marked by red fluorescence. Scale bar $=20 \mu \mathrm{m}$. C: The average length of neurites was determined. D: The number of neurites per cell was counted. Data presented were mean \pm SEM from three independent experiments. Note that the neurite length and number in cells treated only with transfection reagent TransIt-TKO were similar to those transfected with scrambled siRNA
PC12 cells. The transfected cells were then allowed to differentiate by NGF for 5 days. As shown in Figure 1, A and $\mathrm{B}, \mathrm{PC} 12$ cells transfected with control plasmid, pEGFP-N1, as well as those in nontransfected cultures displayed long neurites. When the cells were transfected with PMYOC $_{W T}$-EGFP, the length of neurites was reduced to nearly half of that of pEGFP-N1 controls. The number of neurites was also decreased. Mutant constructs $\mathrm{PMYOC}_{\mathrm{P} 370 \mathrm{~L}}-\mathrm{EGFP}$ and $\mathrm{PMYOC}_{1-367}-\mathrm{EGFP}$ also elicited an inhibitory effect on neurite outgrowth, comparable with that seen with the wild-type myocilin.

By contrast, transfection of the wild-type or the mutant optineurin construct, pOPTN $\mathrm{WT}_{\mathrm{W}}$-EGFP or pOPTN $\mathrm{E} 5 \mathrm{OK}_{\mathrm{K}}$-EGFP, did not induce significant alterations either in the length or the number of neurites in PC12 cells. Expression of the

A
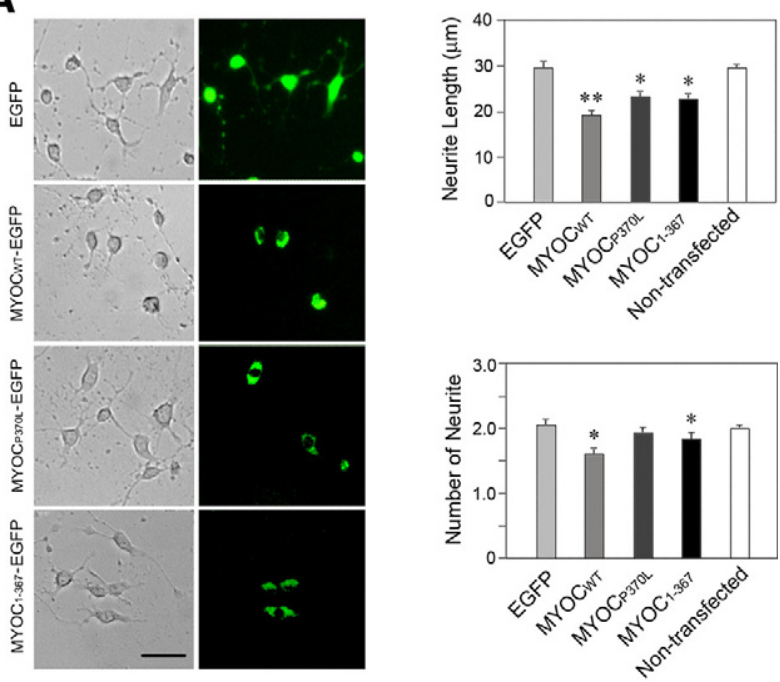

B

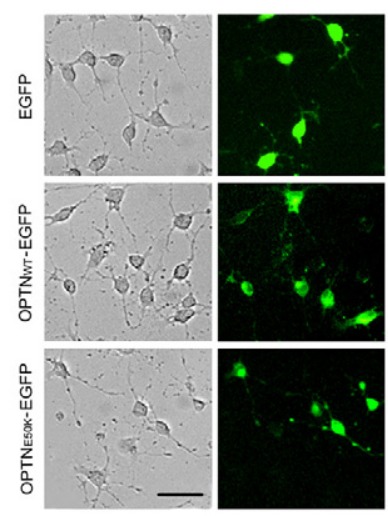

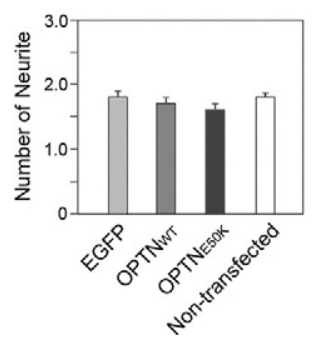

Figure 4. Effects of overexpressed wild-type and mutant myocilin (A) and optineurin (B) on neurite outgrowth in RGC5 cells. The cells were transiently transfected with pEGFP-N1 (mock control), pMYOC $_{\mathrm{WT}}$-EGFP, pMYOC $_{\mathrm{P} 370 \mathrm{~L}}$-EGFP, pMYOC $_{1-367}$-EGFP, pOPTN $\mathrm{WT}_{\mathrm{T}}$-EGFP, or pOPTN $\mathrm{E}_{\mathrm{EOK}}$-EGFP for 48 (for myocilin constructs) or 24 (for optineurin constructs) hours. After washing, the cells were incubated with $316 \mathrm{nmol} / \mathrm{L}$ staurosporine for another 4 hours. The transfected cells were marked by green fluorescence. The average length and the number of neurites were determined. Data presented were mean \pm SEM from three independent experiments. Scale bar $=50 \mu \mathrm{m} .{ }^{*} P<0.045,{ }^{* *} P<0.0004$ 
myocilin- and optineurin-GFP fusion proteins was confirmed by Western blot analyses (Figure 1C).

SiRNA to myocilin that reduced the endogenous level of myocilin (Figure 2A) and siRNA to optineurin that reduced the endogenous level of optineurin (Figure $3 A$ ) affected neither the length nor the number of the neurites (Figures 2, B-D and 3, B-D).

The myocilin and optineurin overexpressing effects were similarly observed with RGC5 cells (Figure 4, Aand B), a neuronal-like cell type with extended neurites. ${ }^{30}$ RGC5 cells transfected with $\mathrm{PMYOC}_{\mathrm{WT}}$-EGFP, $\mathrm{PMYOC}_{\mathrm{P} 370 \mathrm{~L}}-\mathrm{EGFP}$, and PMYOC $_{1-367}$-EGFP barely showed neurites. Those transfected with pOPTN ${ }_{W T}-E G F P$ and POPTN $_{E 50 K}-E G F P$, however, formed neurites to an extent comparable with that observed in pEGFP-N1-transfected and nontransfected cells.

Although inhibition of neurite outgrowth was seen in pMYOC $_{W T}$-EGFP-transfected cells, their nontransfected counterparts in the same cultures were found to possess neurites with lengths and numbers within GFP control or normal limits (Figure 1, A and B). The Western blot data in Figure $1 \mathrm{C}$ documented that the cells transfected with pMYOC $_{W_{T}}$-EGFP secreted abundant myocilin-GFP ( $~ 75$ $\mathrm{kDa}$ ) protein into the media. It appeared that the secreted wild-type myocilin in the medium was either not effective by itself to influence the nontransfected cells in the cultures, or was not internalized into them to exert effects. The nontransfected cells in cultures transfected to express mutant P370L and Q368X myocilin had normal neurite length and number as well. This is unsurprising because both our Western blot data (Figure 1C) and previous reports demonstrated that the mutant forms of myocilin were not secreted or present in the media. ${ }^{20,21}$

\section{Exogenous Myocilin Protein either in Solution or as a Substratum Has Little Effect on Neurite Outgrowth}

Eukaryotically expressed recombinant myocilin protein was added into the media of PC12 cells. Little effect on either the length or the number of neurites induced by NGF was noted (Figure 5, A and B). Furthermore, the length and the number of neurites in PC12 cells plated on a mixture of myocilin $(5 \mu \mathrm{g} / \mathrm{ml})$ and collagen I $(10 \mu \mathrm{g} / \mathrm{ml})$ were comparable with those plated on collagen type I (10 $\mu \mathrm{g} / \mathrm{ml}$ ) alone (Figure 5, A and B).

\section{Effects of Neurite Regulators on the Myocilin Inhibitory Effect}

To examine the mechanism that mediates the inhibitory effect of overexpressed myocilin on neurite outgrowth, factors that are known to regulate neurite formation were added along with NGF onto PC12 cells after transfection with $\mathrm{pMYOC}_{\mathrm{WT}}$-EGFP. Compared with untreated vehicle controls, treatment with Y27632, a Rho-associated protein kinase inhibitor, did not alter the myocilin effect in PC12 cells (Figure 6). 15-Deoxy-PGJ2, a metabolite of prostaglandin D2; PMA, an activator of protein kinase C; and jasplakinolide, an inducer of actin polymerization, also had little effect on the neurite outgrowth in pMYOC $_{W T}$-EGFP-transfected PC12 cells. Forskolin, which increases the intracellular level of cAMP known to play a role in axonal growth and guidance, ${ }^{40}$ was able to avert the myocilin inhibitory effect (Figure 6). However, on a closer examination, forskolin was also seen to increase the neurite length in pEGFP-N1-mock transfected and nontransfected cells (Figure 7). This suggested that the forskolin-mediated neurite stimulation in myocilin-transfected PC12 cells may simply represent a general cAMP effect. Force expressed wild-type myocilin was found to have little impact on the intracellular cAMP level in PC12 cells (data not shown).

\section{FITC-Labeled Myocilin Is not Internalized}

To study whether myocilin is internalized, PC12 and RGC5 cells were incubated with FITC-labeled myocilin protein for 4 hours at $37^{\circ} \mathrm{C}$. FITC-transferrin, the positive control, was taken up, showing an intracellular perinuclear distribution. In comparison, the uptake of FITC- $\beta$ galactosidase (negative control) and FITC-myocilin was minimal (Figure 8).
A
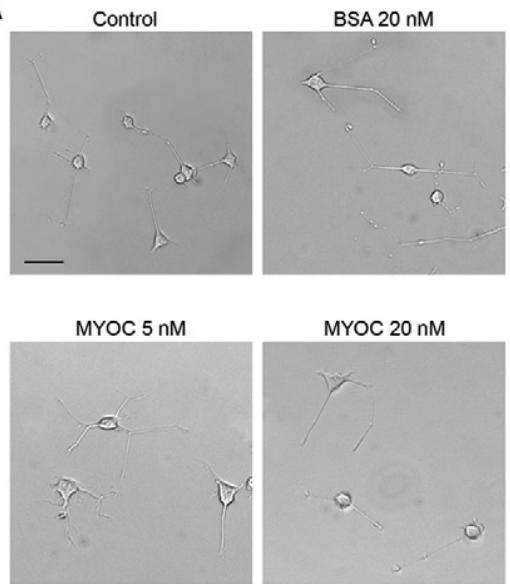

MYOC $20 \mathrm{nM}$

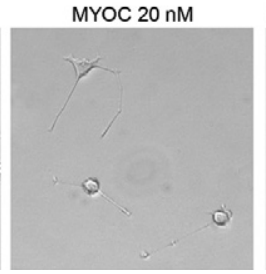

MYOC $1.8 \mathrm{nM}$

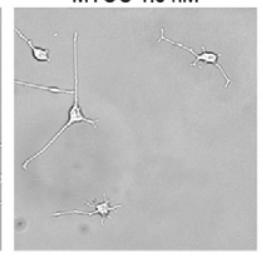

prercoated MYOC $5 \mu \mathrm{g} / \mathrm{ml}$

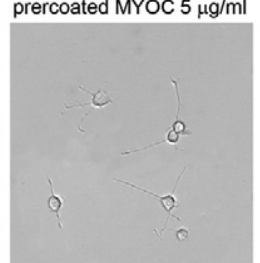

B
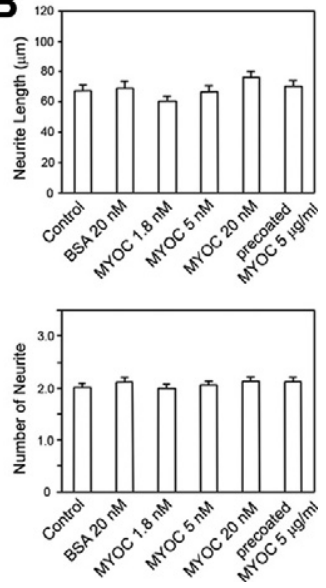

Figure 5. Effect of recombinant myocilin on neurite outgrowth in PC12 cells. A: Cells were plated onto dishes precoated with collagen type I $(10 \mu \mathrm{g} / \mathrm{ml})$. After 24 hours of seeding, PC12 cells were differentiated with NGF without (control) or with recombinant myocilin $(1.8,5$, or 20 $\mathrm{nmol} / \mathrm{L}$ ) for 5 days. Bovine serum albumin (20 $\mathrm{nmol} / \mathrm{L}$ ) was used as a negative control. In parallel, PC12 cells were also plated on collagen type I $(10 \mu \mathrm{g} / \mathrm{ml})$ mixed with recombinant myocilin $(5 \mu \mathrm{g} / \mathrm{ml})$ (precoated MYOC $5 \mu \mathrm{g} / \mathrm{ml}$ ) Scale bar $=50 \mu \mathrm{m}$. B: The neurite length was measured, and the number of neurites was counted in at least 200 cells. Results are expressed as mean \pm SEM. 


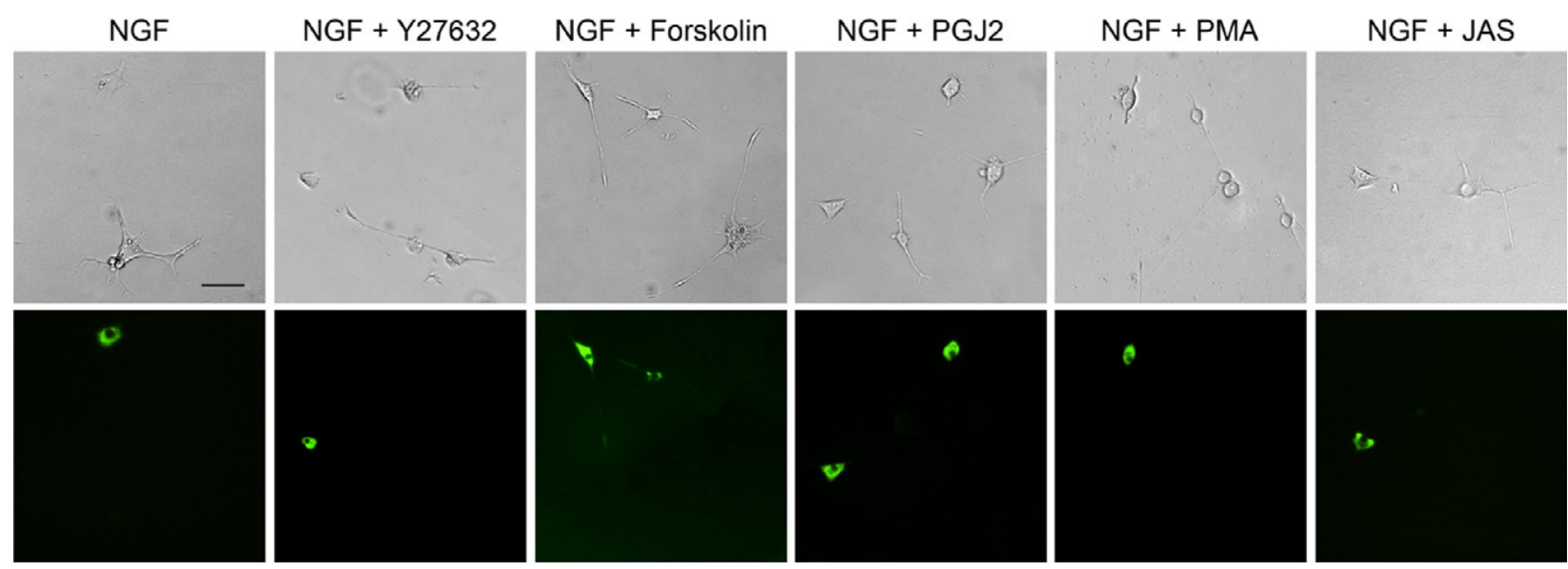

Figure 6. Effects of neurite outgrowth regulators on the myocilin inhibitory phenotype. PC12 cells were transiently transfected with pMYOC ${ }_{\mathrm{WT}}$-EGFP for 48 hours. Y27632 $(10 \mu \mathrm{mol} / \mathrm{L})$, forskolin $(10 \mu \mathrm{mol} / \mathrm{L}), 15$-deoxy-prostagrandin J2 (PGJ2, $0.8 \mu \mathrm{mol} / \mathrm{L})$, PMA $(0.5 \mu \mathrm{mol} / \mathrm{L})$, or jasplakinolide (JAS, $20 \mathrm{nmol} / \mathrm{L}) \mathrm{was}$ then added onto PC12 cells along with NGF and cultured for 5 days. Neurite outgrowth in myocilin transfected (in green) and nontransfected cells was assessed. Scale bar $=$ $50 \mu \mathrm{m}$.

\section{Overexpression of Wild-Type Optineurin Results in Increased Apoptosis}

PC12 and RGC5 cells were transiently transfected for 48 or 24 hours to express GFP alone, wild-type or mutant myocilin-GFP, or optineurin-GFP. Images were captured and the percentage of cells that exhibited activated caspase 3 and 7 enzymes, indicative of apoptotic activity, was determined. Results indicated that the percentage of caspase 3- and 7-positive cells in wild-type myocilin-GFP-overexpressing tansfectants was similar to that in pEGFP-N1-transfected mock controls (Figure 9, A and $B)$. On the other hand, the percentage in cells transfected
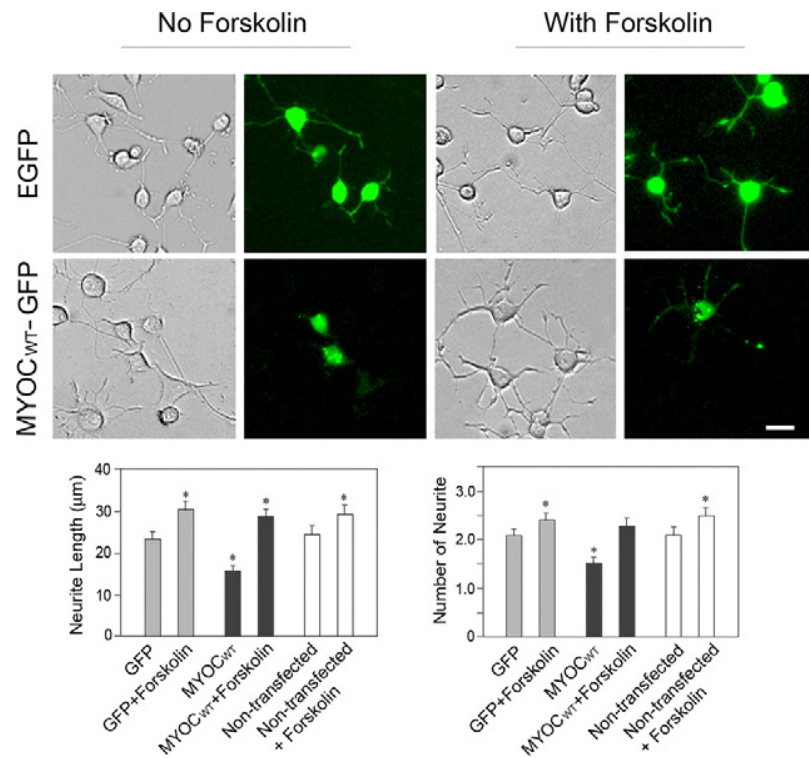

Figure 7. Effect of forskolin on the neurite outgrowth in PC12 cells. The cells were transiently transfected with pEGFP-N1 (EGFP) or PMYOC $_{\mathrm{WT}}$-EGFP

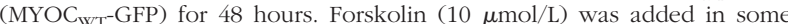
cultures along with NGF and cultured for 5 days. Neurite outgrowth in transfected (in green) and nontransfected cells without or with treatment of forskolin was quantified. Data presented were mean \pm SEM from three independent experiments. ${ }^{*} P<0.008$ compared with GFP control. Scale bar $=20 \mu \mathrm{m}$ to overexpress with wild-type optineurin-GFP was increased by approximately 80 to $100 \%(P<0.0035)$ compared with GFP controls. Higher-than-control values were also observed in cells transfected with P370L and Q368X myocilin and E50K optineurin constructs (Figure 9, $A$ and $B$ )

\section{Discussion}

The present study provides evidence that forced expression of both wild-type and mutant myocilins (Figure 1) inhibits neurite outgrowth in neuronal PC12 and RGC5 cells. PC12 cells have been widely used to study neuronal differentiation and neurite outgrowth. ${ }^{41}$ After stimulation with neurotrophic factors such as NGF, PC12 cells stopped growth and underwent differentiation. RGC5, a rat $\mathrm{RGC}$ cell line established by transforming postnata day 1 rat retinal cells with $\mathrm{E} 1 \mathrm{~A}$ adenovirus, ${ }^{30}$ is a useful model of RGC. ${ }^{42}$

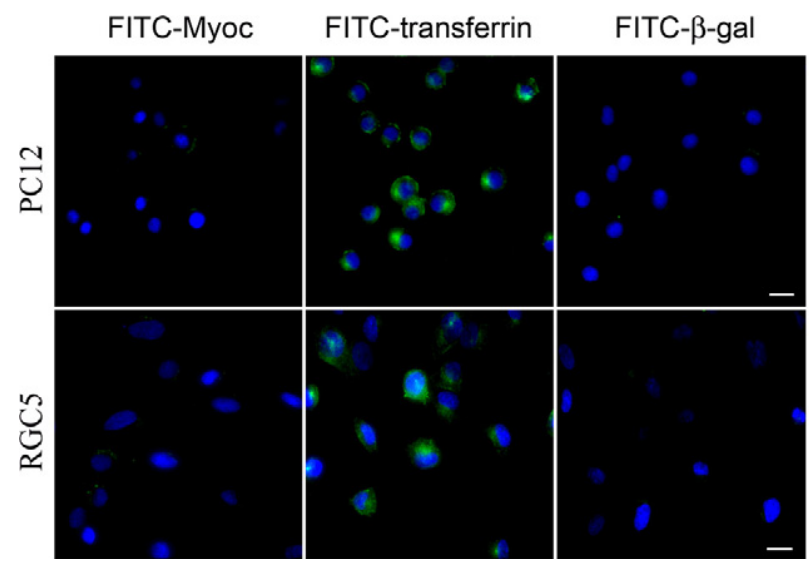

Figure 8. Uptake of FITC-myocilin. PC12 and RGC5 cells were incubated with FITC-labeled myocilin (FITC-Myoc), FITC-labeled transferrin (FITC transferrin, positive control), and FITC-labeled $\beta$-galactosidase (FITC- $\beta$-gal, negative control) at $37^{\circ} \mathrm{C}$ for 4 hours. Intracellular distribution was observed with FITC-transferrin (in green) only. Nuclei were stained with DAPI in blue. Scale bar $=50 \mu \mathrm{m}$. 
A
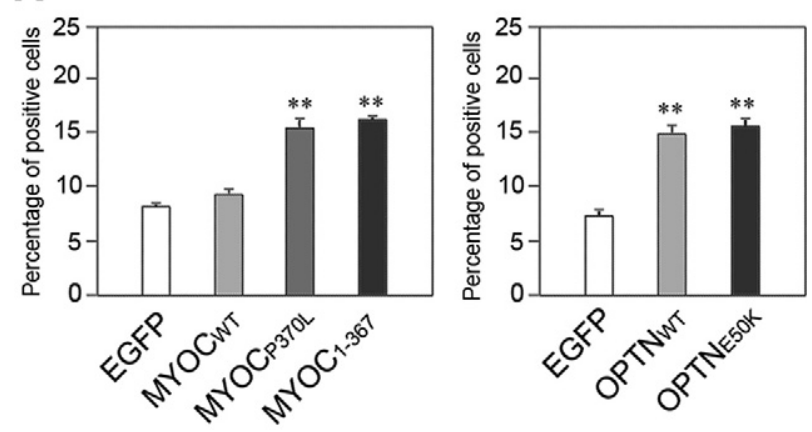

B
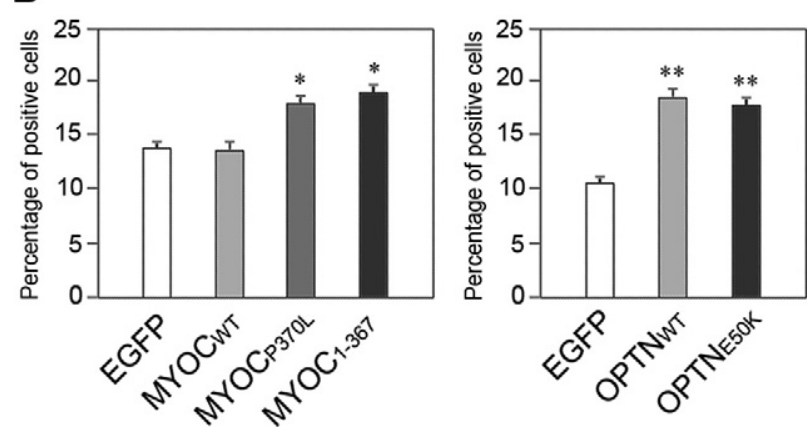

Figure 9. Percentage of caspase3/7-positive apoptotic cells in transfected PC12 (A) and RGC5 (B) cells. The cells were transfected for 72 hours to express wild-type myocilin-GFP ( MYOC $_{\mathrm{WT}}$ ), P370L myocilin-GFP ( MYOC $_{\mathrm{P} 370 \mathrm{~L}}$ ), or Q368X myocilin-GFP ( MYOC $_{1-367}$ ), or for 48 hours to express wild-type optineurin-GFP $\left(\mathrm{OPTN}_{\mathrm{WT}}\right)$ and $\mathrm{E} 50 \mathrm{~K}$ optineurin-GFP $\left(\mathrm{OPTN}_{\mathrm{E} 50 \mathrm{~K}}\right)$ and were examined by a caspase 3 and 7 detection kit. Images in 20 of $10 \times$ fields were captured and cell counting was performed to determine the total number of transfected cells (green) and the number of caspase 3 and 7-positive transfectants (green and red). Percentage of caspase 3- and 7-positive apoptotic cells was calculated. Results from three independent experiments are shown in mean \pm SEM. ${ }^{*} P<0.044$ and ${ }^{* *} P<0.009$ compared with respective mock controls.

Silencing of the endogenous myocilin gene by siRNA did not affect the neurite outgrowth (Figure 2). The inhibitory effect observed with overexpressed myocilin is consistent with a previous result that optimedin, also known as olfactomedin 3, retards neurite outgrowth in NGFinduced PC12 cells. ${ }^{43}$ Myocilin, like optimedin, contains an olfactomedin-like domain. It is possible that this Cterminal olfactomedin-like region contributes to myocilin's inhibitory effect on neurite outgrowth.

In a previous study, ${ }^{44}$ addition of either recombinant myocilin into culture media was shown to inhibit neurite outgrowth in embryonic chick dorsal root ganglions. The present data, however, indicate that neither the addition of soluble recombinant myocilin protein nor the presence of myocilin protein in the substratum affected the neurite length or number in neuronal cells. It is of note that the myocilin protein used previously was expressed in insect Sf9 cells, solubilized, and partially purified by Sephadex G-150 column chromatography. ${ }^{16}$ It has been observed that purify recombinant myocilin from baculovirus and HEK293 cells could result in a cleaved myocilin product. $^{38}$ The myocilin recombinant protein we used was produced by transducing a transformed TM cell line TM5 with full-length myocilin fused to C-terminal V5 and six histidine epitopes, and purified by using Ni column. Only a small proportion of myocilin was cleaved from the TM5myocilin stable cell line and the purification procedure was shown to be highly specific. ${ }^{38}$ Further confirming our data, addition of conditioned media from human TM cells treated with dexamethasone did not show any effect on NGF-induced neurite outgrowth either (data not shown).

The current results also raised the issue whether myocilin protein secreted or that present in the culture medium could be internalized by the cells. Additional experimentation showed that although FITC-labeled transferrin was taken up by the cells efficiently, internalization of FITC-myocilin was not observed. This notion is also supported by the observation that the nontransfected cells in pMyocilin-EGFP-transfected cultures are without myocilin phenotypes. Despite the myocilin-GFP secretion in the medium, the nontransfected cells have normal neurites (Figure 1, A and B) and robust actin stress fibers. ${ }^{45}$ The lack of uptake may also explain in part why Kroeber et $\mathrm{al}^{46}$ did not detect any glaucoma phenotype in their transgenic mice overexpressing wild-type myocilin under the control of lens specific $\beta \mathrm{B} 1$-crystalline promoter ( $\beta$ B1-crystallin-MYOC mice) with abundant myocilin secreted into the aqueous humor.

A number of neurite outgrowth regulators have been identified. ${ }^{41,47}$ For example, Y27632, a Rho-associated protein kinase inhibitor, has been shown to induce neurite outgrowth. ${ }^{48}$ Forskolin, which increases the intracellular level of CAMP, and PMA, an activator of protein kinase C, have also been reported to promote neurite outgrowth in PC12 cells. ${ }^{4,50}$ 15-Deoxy-PGJ2, a metabolite of prostaglandin D2 and a ligand of peroxisome proliferatorsactivated receptor- $\gamma$, is known to induce neurite outgrowth in PC12 cells via activation of p38MAP kinase in conjunction with the AP-1 signal pathway. ${ }^{51,52}$ Regulation of dynamics of actin filament by agents such as jasplakinolide that induce actin polymerization by enhancing actin filament nucleation ${ }^{53}$ has also been shown to be crucial for neurite outgrowth. ${ }^{54}$ In our hands, addition of forskolin but none of the other agents attenuated the inhibitory effect by myocilin overexpression on neurite outgrowth (Figure 6). However, forskolin was also seen to increase the neurite length in both GFP mock transfected and nontransfected cells (Figure 7), suggesting that the attenuation of the myocilin inhibitory effect may simply be a general event and that CAMP may not be a downstream target of overexpressed myocilin. In support of this conjecture, the intracellular CAMP level in PC12 cells was found unaltered by myocilin transfection (data not shown).

In addition, our study indicates that neither wild-type nor E50K optineurin overexpression causes any changes in neurite outgrowth in PC12 (Figure 1) and RGC5 (Figure 4) cells. The lack of functional role of optineurin in neurite outgrowth was further verified by the siRNA experiment (Figure 3).

Myocilin mutations are typically associated with high IOP cases and the optineurin ones are associated with normal tension glaucoma. This implies that myocilin may have more of an impact on the cells in the aqueous outflow pathway such as the TM than those in the optic nerve head and the retina such as RGCs, and vice versa 
in the case of optineurin. Myocilin has previously been shown to affect the actin cytoskeletal structure ${ }^{45,55}$ and to lower the mitochondrial membrane potential ${ }^{56}$ in human TM cells. The revelation that myocilin also impacts neurite outgrowth in neuronal cells is somewhat surprising. On the other hand, in adult eyes, myocilin is expressed in the RGCs, optic nerve axons and photoreceptors. ${ }^{12,57,58}$ Its expression has also been shown to increase in reactive astrocytes in the glial scar. ${ }^{44}$ Hence myocilin may put forth an influence not only on TM cells but also on neurite outgrowth and regeneration. Adult RGCs are reported to have difficulty extending axons within the interior of the optic nerve after injury. ${ }^{59}$ This difficulty has been attributed to inhibitory factors associated with myelin components and the glial scar including Nogos ${ }^{60}$ and chondroitin sulfate proteoglycans. ${ }^{61}$ Myocilin may also be added to this list of inhibitory molecules.

Also, contrary to what were anticipated, optineurin is devoid of effects on neurite outgrowth in neuronal cells. The siRNA results further indicated that optineurin is not a factor involved in the outgrowth of neurites. Overexpression of wild-type optineurin has been shown to cause fragmentation of the Golgi apparatus. ${ }^{36}$ Notably, it also induces apoptosis (Figure 9), which may be an underlying mechanism for pathology, because death of RGCs is a well-documented hallmark feature in glaucoma. ${ }^{62}$

In conclusion, our results demonstrate that the two glaucoma gene products, myocilin and optineurin, exhibit differential effects on neurite outgrowth in neuronal cells. They appear to have different functions and may contribute to the development of neurodegenerative glaucoma via distinct mechanisms.

\section{Acknowledgments}

We thank Dr. Mike Fautsch for generously providing TM5 conditioned medium for preparation of eukaryotic recombinant myocilin, and Ms. Ruth Zelkha for assistance in imaging and image analyses.

\section{References}

1. Bill A: The drainage of aqueous humor. Invest Ophthalmol Vis Sci 1975, 14:1-3

2. Fan BJ, Wang DY, Lam DS, Pang CP: Gene mapping for primary open angle glaucoma. Clin Biochem 2006, 39:249-258

3. Wang DY, Fan BJ, Chua JK, Tam PO, Leung CK, Lam DS, Pang CP: A genome-wide scan maps a novel juvenile-onset primary open angle glaucoma locus to 15 q. Invest Ophthalmol Vis Sci 2006, 47:5315-5321

4. Wiggs JL: Genetic etiologies of glaucoma. Arch Ophthalmol 2007, 125:30-37

5. Sheffield VC, Stone EM, Alward WL, Drack AV, Johnson AT, Streb LM, Nichols BE: Genetic linkage of familial open angle glaucoma to chromosome 1q21-q31. Nat Genet 1993, 4:47-50

6. Stone EM, Fingert JH, Alward LM, Nguyen TD, Polansky JR, Sunden LF, Nishimura D, Clark AF, Nystuen A, Nichols BE, Mackey DA, Ritch R, Kalenak JW, Craven ER, Sheffield VC: Identification of a gene that causes primary open angle glaucoma. Science 1997, 275:668-670

7. Sarfarazi M, Child A, Stoilova D, Brice G, Desai T, Trifan OC, Poinoosawmy D, Crick RP: Localization of the fourth locus (GLC1E) for adult-onset primary open-angle glaucoma to the 10p15-p14 region. Am J Hum Genet 1998, 62:641-652

8. Rezaie T, Child A, Hitchings R, Brice G, Miller L, Coca-Prados M,
Heon E, Krupin T, Ritch R, Kreutzer D, Crick PP, Sarfarazi M: Adultonset primary open-angle glaucoma caused by mutations in optineurin. Science 2002, 295:1077-1079

9. Monemi S, Spaeth G, DaSilva A, Popinchalk S, llitchev E, Liebmann J, Ritch R, Heon E, Crick RP, Child A, Sarfarazi M: Identification of a novel adult-onset primary open-angle glaucoma (POAG) gene on 5q22.1. Hum Mol Genet 2005, 14:725-733

10. Gong G, Kosoko-Lasaki O, Haynatzki GR, Wilson MR: Genetic dissection of myocilin glaucoma. Hum Mol Genet 2004, 13:R91-R102

11. Alward WL, Fingert JH, Coote MA, Johnson AT, Lerner SF, Junqua D, Durcan FJ, McCartney PJ, Mackey DA, Sheffield VC, Stone EM: Clinical features associated with mutations in the chromosome 1 open-angle glaucoma gene (GLC1A). N Engl J Med 1998, 338:1022-1027

12. Hewitt AW, Bennett SL, Fingert JH, Cooper RL, Stone EM, Craig JE, Mackey DA: The optic nerve head in myocilin glaucoma. Invest Ophthalmol Vis Sci 2007, 48:238-243

13. Adam MF, Belmouden A, Binisti P, Brezin AP, Valtot F, Bechetoille A, Dascotte JC, Copin B, Gomez L, Chaventre A, Bach JF, Garchon JF: Recurrent mutations in a single exon encoding the evolutionarily conserved olfactomedin-homology domain of TIGR in familial openangle glaucoma. Hum Mol Genet 1997, 6:2091-2097

14. Rozsa FW, Shimizu S, Lichter PR, Johnson AT, Othman MI, Scott K, Downs CA, Nguyen TD, Polansky J, Richards JE: GLC1A mutations point to regions of potential functional importance on the TIGR/MYOC protein. Mol Vis 1998, 4:20

15. Shimizu S, Lichter PR, Johnson AT, Zhou Z, Higashi M, Gottfredsdottir M, Othman M, Moroi SE, Rozsa FW, Schertzer RM, Clarke MS, Schwartz AL, Downs CA, Vollrath D, Richards JE: Age-dependent prevalence of mutations at the GLC1A locus in primary open-angle glaucoma. Am J Ophthalmol 2000, 130:165-177

16. Nguyen TD, Chen P, Huang WD, Chen H, Johnson D, Polansky JR: Gene structure and properties of TIGR, an olfactomedin-related glycoprotein cloned from glucocorticoid-induced trabecular meshwork cells. J Biol Chem 1998, 273:6341-6350

17. Wentz-Hunter K, Ueda J, Yue BYJT: Protein interactions with myocilin Invest Ophthalmol Vis Sci 2002, 43:176-182

18. Fautsch MP, Vrabel AM, Johnson DH: The identification of myocilinassociated proteins in the human trabecular meshwork. Exp Eye Res 2006, 82:1046-1052

19. Gobeil S, Letartre L, Raymond V: Functional analysis of the glaucomacausing TIGR/myocilin protein: integrity of amino-terminal coiled-coil regions and olfactomedin homology domain is essential for extracellular adhesion and secretion. Exp Eye Res 2006, 82:1017-1029

20. Jacobson N, Andrews M, Shepard AR, Nishimura D, Searby C, Fingert JH, Hageman G, Mullins R, Davidson BL, Kwon YH, Alward WL, Stone EM, Clark AF, Sheffield VC: Non-secretion of mutant proteins of the glaucoma gene myocilin in cultured trabecular meshwork cells and in aqueous humor. Hum Mol Genet 2001, 10:117-125

21. Liu Y, Vollrath D: Reversal of mutant myocilin non-secretion and cell killing: implications for glaucoma. Hum Mol Genet 2004, 13:1193-1204

22. Yam GH, Gaplovska-Kysela K, Zuber C, Roth J: Aggregated myocilin induces Russell bodies and causes apoptosis: implications for the pathogenesis of myocilin-caused primary open-angle glaucoma. Am J Pathol 2007, 170:100-109

23. Sarfarazi M, Rezaie T: Optineurin in primary open angle glaucoma Ophthalmol Clin North Am 2003, 16:529-541

24. Hauser MA, Sena DF, Flor J, Walter J, Auguste J, Larocque-Abramson K, Graham F, Delbono E, Haines JL, Pericak-Vance MA, Allingham R, Wiggs JL: Distribution of optineurin sequence variations in an ethnically diverse population of low-tension glaucoma patients from the United States. J Glaucoma 2006, 15:358-363

25. Ayala-Lugo RM, Pawar H, Reed DM, Lichter PR, Moroi SE, Page M, Eadie J, Azocar V, Maul E, Ntim-Amponsah C, Bromley W, ObengNyarkoh E, Johnson AT, Kijek TG, Downs CA, Johnson JM, PerezGrossmann RA, Guevara-Fujita ML, Fujita R, Wallace MR, Richards JE: Variation in optineurin (OPTN) allele frequencies between and within populations. Mol Vis 2007, 13:151-163

26. Aung T, Rezaie T, Okada K, Viswanathan AC, Child AH, Brice G, Bhattacharya SS, Lehmann OJ, Sarfarazi M, Hitchings RA: Clinical features and course of patients with glaucoma with the E50K mutation in the optineurin gene. Invest Ophthalmol Vis Sci 2005, 46:2816-2822

27. Li Y, Kang J, Horwitz MS: Interaction of an adenovirus E3 14.7kilodalton protein with a novel tumor necrosis factor $\alpha$-inducible cel- 
lular protein containing leucine zipper domains. Mol Cell Biol 1998, 18:1601-1610

28. Rezaie T, Sarfarazi M: Molecular cloning, genomic structure, and protein characterization of mouse optineurin. Genomics 2005, 85:131-138

29. Greene LA, Tischler AS: Establishment of a noradrenergic clonal line of rat adrenal pheochromocytoma cells which respond to nerve growth factor. Proc Natl Acad Sci USA 1976, 73:2424-2428

30. Krishnamoorthy RR, Agarwal P, Prasanna G, Vopat K, Lambert W, Sheedlo HJ, Pang IH, Shade D, Wordinger RJ, Yorio T, Clark AF, Agarwal $\mathrm{N}$ : Characterization of a transformed rat retinal ganglion cell line. Brain Res Mol Brain Res 2001, 86:1-12

31. Park BC, Tibudan M, Samaraweera M, Shen X, Yue BYJT: Interaction between two glaucoma genes, optineurin and myocilin. Genes Cells 2007, 12:969-979

32. Choi J, Miller AM, Nolan MJ, Yue BYJT, Thotz ST, Clark AF, Agarwal N, Knepper PA: Soluble CD44 is cytotoxic to trabecular meshwork and retinal ganglion cells in vitro. Invest Ophthalmol Vis Sci 2005, 46:214-222

33. Park BC, Shen X, Fautsch MP, Tibudan M, Johnson DH, Yue BYJT: Optimized bacterial expression of myocilin proteins and functional comparison of bacterial and eukaryotic myocilins. Mol Vis 2006, 12:832-840

34. Wentz-Hunter K, Ueda J, Shimizu N, Yue BYJT: Myocilin is associated with mitochondria in human trabecular meshwork cells. J Cell Physiol 2002, 190:46-53

35. Wentz-Hunter K, Kubota R, Shen X, Yue BYJT: Extracellular myocilin affects activity of human trabecular meshwork cells. J Cell Physiol 2004, 200:45-52

36. Park BC, Shen X, Samaraweera M, Yue BYJY: Studies of optineurin, a glaucoma gene: Golgi fragmentation and cell death from overexpression of wild-type and mutant optineurin in two ocular cell types. Am J Pathol 2006, 169:1976-1989

37. Schwechter BR, Millet LE, Levin LA: Histone deacetylase inhibitionmediated differentiation of RGC5 cells and interaction with survival. Invest Ophthalmol Vis Sci 2007, 48:2845-2857

38. Fautsch MP, Bahler CK, Vrabel AM, Howell KG, Loewen N, Teo WL, Poeschla EM, Johnson DH: Perfusion of HIS-tagged eukaryotic myocilin increases outflow resistance in human anterior segments in the presence of aqueous humor. Invest Ophthalmol Vis Sci 2006, 47:213-221

39. Sakai H, Park BC, Shen X, Yue BYJT: Transduction of TAT-fusion proteins into the human and bovine trabecular meshwork. Invest Ophthalmol Vis Sci 2006, 47:4427-4424

40. Han J, Han L, Tiwari P, Wen Z, Zheng JQ: Spatial targeting of type II protein kinase $A$ of filopodia mediates the regulation of growth cone guidance by cAMP. J Cell Biol 2007, 176:101-111

41. Laketa V, Simpson JC, Bechtel S, Wiemann S, Pepperkok R: Highcontent microscopy identifies new neurite outgrowth regulators. Mol Biol Cell 2007, 18:242-252

42. Chalasani ML, Radha V, Gupta V, Agarwal N, Balasubramanian D, Swarup G: A glaucoma-associated mutant of optineurin selectively induces death of retinal ganglion cells which is inhibited by antioxidants. Invest Ophthalmol Vis Sci 2007, 48:1607-1614

43. Lee HS, Tomarev SI: Optimedin induces expression of $\mathrm{N}$-cadherin and stimulates aggregation of NGF-stimulated PC12 cells. Exp Cell Res 2007, 313:98-108

44. Jurynec MJ, Riley CP, Gupta DK, Nguyen TD, McKeon RJ, Buck CR: TIGR is upregulated in the chronic glial scar in response to central nervous system injury and inhibits neurite outgrowth. Mol Cell Neurosci 2003, 23:69-80

45. Shen X, Koga T, Park BC, SundarRaj N, Yue BYJT: Rho GTPase and CAMP/PKA signaling mediates myocilin induced alterations in cultured human trabecular meshwork cells. J Biol Chem 2008, 283: 603-612

46. Kroeber M, Ohlmann A, Russell P, Tamm ER: Transgenic studies on the role of optineurin in the mouse eye. Exp Eye Res 2006, 82:1075-1085

47. Da Silva JS, Dotti CG: Breaking the neuronal sphere: regulation of the actin cytoskeleton in neuritogenesis. Nat Rev Neurosci 2002, 3:694-704

48. Hirose M, Ishizaki T, Watanabe N, Uehata M, Kranenburg O, Moolenaar WH, Matsumura F, Maekawa M, Bito H, Narumiya S: Molecular dissection of the Rho-associated protein kinase (p160ROCK)-regulated neurite remodeling in neuroblastoma N1E-115 cells. J Cell Biol 1998, 141: 1625-1636

49. Richter-Landsberg C, Jastorff B: The role of CAMP in nerve growth factor-promoted neurite outgrowth in PC12 cells. J Cell Biol 1986, 102:821-829

50. Larsson C: Protein kinase $\mathrm{C}$ and the regulation of the actin cytoskeleton. Cell Signal 2006, 18:276-284

51. Satoh T, Furuta K, Suzuki M, Watanabe Y: Prostaglandin J2 and its metabolites promote neurite outgrowth induced by nerve growth factor in PC12 cells. Biochem Biophys Res Commun 1999, 258:50-53

52. Jung KM, Park KS, Oh JH, Jung SY, Yang KH, Song YS, Son DJ, Park YH, Yun YP, Lee MK, Oh KW, Hong JT: Activation of p38 mitogenactivated protein kinase and activator protein-1 during the promotion of neurite extension of PC-12 cells by 15 -deoxy- $\Delta 12,14$-prostaglandin J2. Mol Pharmacol 2003, 63:607-616

53. Bubb MR, Spector I, Beyer BB, Fosen KM: Effects of jasplakinolide on the kinetics of actin polymerization. An explanation for certain in vivo observations. J Biol Chem 2000, 275:5163-5170

54. Dent EW, Gertler FB: Cytoskeletal dynamics and transport in growth cone motility and axon guidance. Neuron 2003, 40:209-227

55. Goldwich A, Scholz M, Tamm ER: Myocilin promotes substrate adhesion, spreading and formation of focal contacts in podocytes and mesangial cells. Histochem Cell Biol 2009, 131:167-180

56. Sakai H, Shen X, Koga T, Park BC, Noskina Y, Tibudan M, Yue BYJT: Mitochondrial association of myocilin in human trabecular meshwork cells. J Cell Physiol 2007, 213:775-784

57. Karali A, Russell P, Stefani FH, Tamm ER: Localization of myocilin/ trabecular meshwork-inducible glucocorticoid response protein in the human eye. Invest Ophthalmol Vis Sci 2000, 41:729-740

58. Clark AF, Kawase K, English-Wright S, Lane D, Steely HT, Yamamoto T, Kitazawa Y, Kwon YH, Fingert JH, Swiderski RE, Mullins RF, Hageman GS, Alward WL, Sheffield VC, Stone EM: Expression of the glaucoma gene myocilin (MYOC) in the human optic nerve head. FASEB J 2001, 15:1251-1253

59. Charalambous P, Hurst LA, Thanos S: Engrafted chicken neural tube-derived stem cells support the innate propensity for axonal regeneration within the rat optic nerve. Invest Ophthalmol Vis Sci 2008, 49:3513-3524

60. Schwab ME: Nogo and axon regeneration. Curr Opin Neurobiol 2004, 14:118-124

61. Busch SA, Silver J: The role of extracellular matrix in CNS regeneration. Curr Opin Neurobiol 2007, 17:120-127

62. Kuehn $\mathrm{MH}$, Fingert $\mathrm{JH}$, Kwon $\mathrm{YH}$ : Retinal ganglion cell death in glaucoma: mechanisms and neuroprotective strategies. Ophthalmol Clin North Am 2005, 18:383-395 